\title{
Enhancing Students' Motivation to Learn Arabic Through Method of Muhadharah
}

\author{
${ }^{1}$ Nurmadiah, ${ }^{2}$ Sitti Sakinah, ${ }^{3}$ Helaluddin, ${ }^{4}$ Hengki Wijaya \\ \{rnurmadiah@gmail.com ${ }^{1}$, sakinah_sitti@gmail.com ${ }^{2}$, helaluddin@uinbanten.ac.id ${ }^{3}$, \\ hengkiwijaya@sttjaffray.ac.id $\left.{ }^{4}\right\}$ \\ Universitas Indonesia Timur, Indonesia ${ }^{1,2}$ \\ Islamic State University of Sultan Maulana Hasanuddin Banten, Jalan Jendral Sudirman No. 30 \\ Panancangan Cipocok Jaya, Sumurpecung, Kota Serang, Banten ${ }^{3}$ \\ Sekolah Tinggi Filsafat Jaffray Makassar, Jalan Gunung Merapi 103 Makassar, Sulawesi Selatan ${ }^{4}$
}

\begin{abstract}
This paper aims to determine the effect of the Muhadharah method on the motivation to learn Arabic for junior high school students in the Darul Aman Gombara Islamic Boarding School, and to find out the factors that inhibit Muhadharah's method of increasing motivation to learn Arabic. The results of this study indicate that: 1) the Muhadharah method has an effect on the process of enhancing the motivation to learn Arabic in students of the Darul Aman Gombara Islamic Boarding School; 2) the factors that influence the Muhadharah method are short time, less effective place, less varied ways, inadequate facilities and infrastructure, and little foreign language vocabulary.
\end{abstract}

Keywords: Muhadharah, public speaking, motivation, language, Arabic, Islamic

\section{Introduction}

Teaching foreign languages in general Muhadharah or lectures can be equated with rhetoric (Greek) or public speaking (English). Muhadharah means that it is an art of delivering the word verbally whose contents can vary. According to Luqman Hadinegoro, the meaning of Muhadharah or lecture is the expression of thoughts in the form of words addressed to the people, or discourses prepared to be spoken in front of the audience so that the listeners and lectures can understand, know, and be able to implement everything that is conveyed to them. Muhadharah or lecture is also the art of public speaking [1]. The method of Muhadharah (public speaking) is an oral presentation of information using foreign languages especially with the use of Arabic both formal and informal [2]. This study aims to increase motivation to learn through the Muhadharah method and find out the factors that hinder the use of the Muhadharah method in enhancing student learning motivation. 


\section{Review of Literature}

\subsection{Muhadharah (Public Speaking)}

Muhadharah is an activity or practice of speeches or lectures that are emphasized in the skills of students using foreign languages. The technique of using words or language effectively is the skill in choosing words that can affect the communicant according to the situation and condition of the communicant. According to Setiawan [3], "This lecture method is more flexible." It means that it is easily adapted to the situation and conditions and the time available, if the limited time of material can be shortened. And vice versa if the time allows as much as possible and more profound material can be delivered. Public speaking is a continuous process of communication in which messages and symbols continually re-circulate between the speaker and his audience [4]. According to Lucas argue "the are four basic methods of delivering a speech: reading verbatim from the manuscript, reciting a memorized text, speaking impromptu and extemporaneously,"[5]. Research also shows that public speaking skills are essential, useful for entertaining, answering questions, and discussing in groups [6].The purpose of Muhadharah in the context of satisfying listeners is 1) providing new information or adding new knowledge or insights; 2) influence (persuasive public speaking) speaker; 3) entertaining (reactive public speaking), namely the speaker aims to entertain and create a cheerful atmosphere.

\subsection{Student Motivation to Learn}

Dörnyei reveals the motivation to learn languages, namely: 1) students learn a second language to travel; 2) to seek new friendships; 3) to obtain knowledge, and 4) for instrumental purposes; 5) sociocultural orientation [7].There is two motivations namely assimilative and integrative motivation. The assimilative motivation is referring to the drive to become an indistinguishable member of the community. This type of motivation is distinct from integrative motivation, which involves a desire to establish a social relationship with the target language community, without implying or requiring direct contact with a target-language peer group. On the other hand, assimilative motivated learning must take place in the host environment [7].Based on the theory of self-determination, motivation is divided into two parts, namely intrinsic and extrinsic motivation. Intrinsic motivation comes from within oneself which encourages a person to do something pleasant and satisfying to do. While extrinsic motivation is the drive to achieve something that produces appreciation, and avoid punishment [8]. Therefore, the teacher motivates students to get awards and plays an active role in learning foreign languages. Their effort determines learners' motivation to acquire a second language, a perception of the degree of attractiveness of the goals (valence), understanding of the probability of attaining the goals (expectancy), and appraisal of their ability to achieve the goals [9]. Motivation plays a vital role in attaining proficiency in second language learning [10]. Confidence and cultural interest are motivational factors for learning foreign languages [11]. 


\section{Research Methodology}

The type of research used is a type of quantitative data, namely data obtained in the form of numbers that can be calculated, which are related to the problems studied at the Darul Aman Gombara Islamic Boarding School in Makassar. Random sampling technique where the total population is 218 respondents and researchers take $25 \%$ of the population. The number of samples of 55 respondents was distributed questionnaires to be processed in this study. Interview in Focus Group Discussion [12]. Focus group interview is one of the valuable tools for collecting qualitative data [13]. The results of the study will be described in the study discussion.

\section{Discussion And Results}

\subsection{The Effect of the Muhadharah Method on the Motivation of Learning Arabic}

The method of Muhadharah according to Iskandar as a director at the Darul Aman Makassar Islamic Boarding School in the results of his interview is that the Muhadharah method is essential because it is fundamental in conveying the vision of an Islamic mission through Arabic. Besides Muhadharah are:

1. A form of training conducted by students.

2. Train yourself how to appear in front of many people because the pesantren is like a small community where students come from various tribes who are then trained to perform in public.

3. Providing the children not to be stiff when in the school.

4. Providing high psychological motivation to adolescents that conveying religion through Arabic is something that is not difficult and there is satisfaction.

5. The Muhadharah method is a method of developing Arabic that must be communicated to encourage each student's enrichment regarding of language vocabulary and selfconfidence for students.

According to Ratna Hafid as an Arabic teacher at the Makassar Darul Aman Gombara Islamic Boarding School regarding the method of Muhadharah, it certainly improves students' language skills so that every year it is intensified with the activities of Muhadharah. The illustrates the strength of students' language by being strengthened by the English camp and Arabic camp activities.

Table 1. The Muhadharah method is useful to apply to junior high school students

\begin{tabular}{lcc}
\hline Answer category & Frequency & Percentage \\
\hline Strongly agree & 40 & $72,7 \%$ \\
Agree & 15 & $27,3 \%$ \\
Disagree & - & - \\
Strongly disagree & - & - \\
\hline
\end{tabular}

The table above shows that $72.7 \%$ stated that they strongly agreed that the Muhadharah method was applied to junior high school students at the Darul Aman Gombara Islamic 
Boarding School in Makassar and 27.3\% agreed. All students agree that the Muhadharah method is useful in applying to learn.

Table 2. The Muhadharah Method Can enhance Language Learning Motivation

\begin{tabular}{lcc}
\hline Answer category & Frequency & Percentage \\
\hline Strongly agree & 47 & $85,5 \%$ \\
Agree & 8 & $14,5 \%$ \\
Disagree & - & - \\
Strongly disagree & - & - \\
\hline
\end{tabular}

The table above shows that $85.5 \%$ of respondents stated that they strongly agreed and $14.5 \%$ of respondents indicated that they decided that the Muhadharah method could increase motivation to learn Arabic in junior high school students at the Darul Aman Gombara Islamic Boarding School in Makassar. Thus $100 \%$ agree.

Table 3. The Muhadharah method is the only method that can increase the motivation to learn Arabic

\begin{tabular}{lcc}
\hline Answer category & Frequency & Percentage \\
\hline Strongly agree & 36 & $65,5 \%$ \\
Agree & 12 & $21,8 \%$ \\
Disagree & 7 & $12,7 \%$ \\
Strongly disagree & - & - \\
\hline
\end{tabular}

The table above shows that $65.5 \%$ of respondents stated that they strongly agreed and $21.8 \%$ of respondents indicated that they accepted and only $12.7 \%$ of respondents answered that they did not receive if the method of Muhadharah was the only method that could improve motivation to learn Arabic.

Table 4. The Muhadharah Method Greatly Helps Students in the Process of Adding Arabic vocabulary

\begin{tabular}{lcc}
\hline Answer category & Frequency & Percentage \\
\hline Strongly agree & 50 & $90,9 \%$ \\
Agree & 5 & $9,1 \%$ \\
Disagree & - & - \\
Strongly disagree & - & - \\
\hline
\end{tabular}

The table above shows that $90.9 \%$ of respondents stated that they strongly agreed and 9.1\% of respondents indicated that they decided that the Muhadharah method could help students in adding Arabic vocabulary, and no one stated disagreement.

Table 5. Students Like Learning Arabic using the Muhadharah Method

\begin{tabular}{lcc}
\hline Answer category & Frequency & Percentage \\
\hline Strongly agree & 36 & $65,5 \%$ \\
Agree & 19 & $34,5 \%$ \\
Disagree & - & - \\
Strongly disagree & - & - \\
\hline
\end{tabular}


The table above shows that $65.5 \%$ of respondents stated that they strongly agreed and $34.5 \%$ of respondents said they decided to learn Arabic using the Muhadharah method which is often carried out in Islamic boarding schools.

The author can answer the first problem statement that the Muhadharah method is significant for increasing motivation to learn Arabic. The results showed that students as a whole agreed with the Muhadharah learning method to have a good impact for students to have the motivation to learn Arabic and to help improve their Arabic vocabulary.

\subsection{The Form of Activity of Muhadharah}

According to the Chairperson of the Student Organization at the Makassar Darul Aman Gombara Islamic Boarding School that Muhadharah activities have been running according to a predetermined schedule, although there are several inhibiting factors. As Chair, I motivate myself to be actively involved in Muhadharah activities and encourage students or peers to learn Arabic through these activities actively.

The forms in Muhadharah activities are:

1. Opened by the Master of Ceremonies, which uses three languages (Arabic, English, and Indonesian).

2. Recitation of the Holy Qur'an and saritilawah (the art reads the meaning of Al-Qur'an with a beautiful narrative with its mimic and expression service by with what is in the meaning of Al-Qur'an which he read) and while the saritilawah reading uses two languages namely English, and Indonesian).

3. Short lectures using three languages (Arabic, English, and Indonesian).

4. The selection of three participants randomly (without prior notice) is tasked with concluding the results of the lecture delivered by the speaker.

5. Rest and entertainment, where entertainment is usually done in groups. The show contained poetry, drama, and nasyid (one of the Islamic arts in the field of sound art) and used three languages (Arabic, English, and Indonesian).

The description of the data on the form of Muhadharah activities at the Darul Aman Gombara Islamic Boarding School in Makassar is as follows.

Table 6. Implementation of the Muhadharah Method is well implemented

\begin{tabular}{lcc}
\hline Answer category & Frequency & Percentage \\
\hline Strongly agree & 44 & $80 \%$ \\
Agree & 7 & $12,7 \%$ \\
Disagree & 4 & 7,3 \\
Strongly disagree & - & - \\
\hline
\end{tabular}

The table above shows that $80 \%$ of respondents stated strongly agree and $12.7 \%$ stated that the implementation of the Muhadharah method was well implemented and only $7.3 \%$ of respondents said they did not decide that the application did not go according to the objectives of the activity. As an evaluation of these activities, it was found that several factors were inhibiting the implementation of Muhadharah activities at the Islamic Boarding School. 


\subsection{Factors Inhibiting the Implementation of the Muhadharah Method in Increasing Motivation to Learn Arabic}

The description of the data on the inhibiting factors of the Muhadharah method in increasing motivation to learn Arabic can be seen from the results of the questionnaire that has been distributed as follows:

Table 7. The Muhadharah method has inhibiting factors that influence student motivation in learning Arabic

\begin{tabular}{lcc}
\hline Answer category & Frequency & Percentage \\
\hline Strongly agree & 29 & $52,7 \%$ \\
Agree & 17 & $30,9 \%$ \\
Disagree & 9 & $16,4 \%$ \\
Strongly disagree & - & - \\
\hline
\end{tabular}

The table above shows $52.7 \%$ of respondents stated strongly agree and $30.9 \%$ of respondents noted that the method of Muhadharah had an inhibiting factor so that students who were less motivated to learn Arabic, while $16.4 \%$ of respondents said they did not agree if the Muhadharah method had many factors inhibit students from learning Arabic. According to the head of the student organization at the Darul Aman Gombara Islamic Boarding School which is the inhibiting factors in the Muhadharah method are: 1) Short time; 2) Places that are less effective; 3) Less varied ways; 4) Inadequate facilities and infrastructure; 5) Foreign language vocabulary that is little or less.

The teacher's role is crucial to motivating students to learn Arabic by using the method of Muhadharah with the limitations mentioned above. Although there are inhibiting factors, Cohen \& Norst [14] argues that "unrelenting teacher care, support, positive attitude, encouragement, kindness, and patience can help overcome anxiety in time." The motivation to learn Arabic is more important than knowledge and language technical skills [14].

The motivated individual is goal-directed,expends effort, is persistent, is attentive, has desires (wants), exhibits positive affect, is aroused, has expectancies, demonstrates selfconfidence (self-efficacy), and has reasons (motives) [15]. In their research, we have found that we can tap into motivation regarding of three measures which touch the cognitive, affective and behavioral components.

Table 8. The Muhadharah Method Requires Many Variations in Learning Arabic

\begin{tabular}{lcc}
\hline Answer category & Frequency & Percentage \\
\hline Strongly agree & 43 & $78,2 \%$ \\
Agree & 11 & $20 \%$ \\
Disagree & 1 & $1,8 \%$ \\
Strongly disagree & - & - \\
\hline
\end{tabular}

The table above shows $78.2 \%$ of respondents stated that they strongly agreed, and $20 \%$ of respondents agreed, while only $1.8 \%$ of respondents said they did not decide that the Muhadharah method requires a lot of variety.

The teacher needs to use several variations in implementing the Muhadharah method, especially in Arabic as a foreign language. Henderson \& Wellington argue that teachers have 
become more aware of the language they use in speaking and writing. But for the pupil, the language barrier remains as real as ever in science and for many continues to be the main obstacle to their learning. Teachers still need to concentrate on how language is interpreted rather than just its transmission. It is hoped that the practical strategies offered here will help in overcoming the language barrier to learning [16].

The motivation for learning foreign languages can be improved by paying attention to the learning strategies used to apply a teaching method [17]. The strategies include copying the teacher's words as native speakers, using vocabulary in different ways, watching movies, listening to songs with lyrics, motivating oneself to dare to speak Arabic in class, and practicing with students to talk to Arabic with simple conversations.

Through the Focus Group Discussion, the authors explain that the inhibiting factors in the Muhadharah method in improving motivation to learn Arabic are:

1. The time is too short, and the place is less effective so that sometimes there are students who pay less attention to the Muhadharah method and consequently sometimes there are students who lack interest in the Arabic learning process, besides the methods that are less varied so sometimes students get bored with the Muhadharah method.

2. Inadequate facilities and infrastructure, and vocabulary of foreign languages which are a little consequently sometimes students do not believe in developing their language skills.

\section{Conclusion}

Based on the results of the study, the author answers the formulation of the problem described earlier. The conclusions are:

1. The Muhadharah method is very influential in increasing the motivation to learn Arabic. And the Muhadharah method is one of the very basic or essential things in the development of Arabic because it is a matter that must be communicated to enhance students' vocabulary.

2. The inhibiting factors in the Muhadharah method are:

a. Short time.

b. A less effective place.

c. Less various methods.

d. Inadequate facilities and infrastructure.

e. Little foreign language vocabulary.

3. The Muhadharah method is more effective when accompanied by a variety of learning strategies to motivate students to be more interested in learning Arabic with forms of activities combined with similar events such as English Camp, or Indonesian camp.

\section{References}

[1] L. Hadinegoro, Teknik Seni Berpidato Mutakhir. Yogyakarta: Absolut, 2007.

[2] E. Erlis, N. Juita, and I. Basri, "Tindak Tutur Direktif Guru Dalam Kegiatan Muhadarah Di MTsN Lubuk Buaya Kota Padang," Bahasa, Sastra, dan Pembelajaran, vol. 2, no. 3, 2014.

[3] E. Setiawan, "Strategi Muhadharah Sebagai Metode Pelatihan Dakwah Bagi Kader Da'i Di Pesantren Daarul Fikri Malang," Fenomena, vol. 14, no. 2, Mar. 2016.

[4] D. Zarefsky, Public speaking: strategies for success, Eighth edition. New York, NY: Pearson, 2017. 
[5] S. E. Lucas, The Art of Public Speaking. New York, NY: McGraw-Hill, 2004.

[6] J. R. Johnson and N. Szczupakiewicz, "The Public Speaking Course: Is It Preparing Students With Work-Related Public Speaking Skills?," Communication Education, vol. 36, pp. 131-137, 1987.

[7] Z. Dörnyei, "Conceptualizing Motivation in Foreign-Language Learning*," Language Learning, vol. 40, no. 1, pp. 45-78, Mar. 1990.

[8] K. A. Noels, L. G. Pelletier, R. Clément, and R. J. Vallerand, "Why Are You Learning a Second Language? Motivational Orientations and Self-Determination Theory," Language Learning, vol. 50, no. 1, pp. 57-85, Mar. 2000.

[9] K. A. Shaaban and G. Ghaith, "Student Motivation to Learn English as a Foreign Language," Foreign Language Annals, vol. 33, no. 6, pp. 632-644, Nov. 2000.

[10] H. Sung and A. M. Padilla, "Student Motivation, Parental Attitudes, and Involvement in the Learning of Asian Languages in Elementary and Secondary Schools," The Modern Language Journal, vol. 82, no. 2, pp. 205-216, Jun. 1998.

[11] K. Csizer and Z. Dornyei, "The Internal Structure of Language Learning Motivation and Its Relationship with Language Choice and Learning Effort," The Modern Language Journal, vol. 89, no. 1, pp. 19-36, Mar. 2005.

[12] D. D. F. Kinalski, C. C. de Paula, S. M. de M. Padoin, E. T. Neves, R. E. Kleinubing, and L. F. Cortes, "Focus group on qualitative research: experience report," Revista Brasileira de Enfermagem, vol. 70, no. 2, pp. 424-429, Apr. 2017.

[13] R. M. Dilshad and M. I. Latif, "Focus Group Interview as a Tool for Qualitative Research: An Analysis," Pakistan Journal of Social Sciences, vol. 33, no. 1, pp. 191-198, 2013.

[14] Y. Cohen and M. J. Norst, "Fear, Dependence and Loss of Self-Esteem: Affective Barriers in Second Language Learning Among Adults," RELC Journal, vol. 20, no. 2, pp. 61-77, Dec. 1989.

[15] M. Williams, R. Burden, and U. Lanvers, "'French is the Language of Love and Stuff': Student perceptions of issues related to motivation in learning a foreign language," British Educational Research Journal, vol. 28, no. 4, pp. 503-528, Aug. 2002.

[16] J. Henderson and J. Wellington, "Lowering the language barrier in learning and teaching science," School Science Review, vol. 79, no. 288, pp. 35-46, 1998.

[17] G. Wharton, "Language Learning Strategy Use of Bilingual Foreign Language Learners in Singapore," Language Learning, vol. 50, no. 2, pp. 203-243, Jun. 2000. 